\title{
INOVASI PEMERINTAH DAERAH DALAM PELAKSANAAN PROGRAM SMART CARD DI KOTA MAKASSAR
}

\author{
Muchlas M. Tahir ${ }^{1}$ dan Ahmad Harakan ${ }^{2}$ \\ 1Muchlasmtahir7@gmail.com dan 2ahmadharakan@gmail.com
}

\begin{abstract}
ABSTRAK
Penelitian ini bertujuan untuk mengetahui Bagaimana Pelaksanaan Program Smart Card sebagai Inovasi Pemerintah Daerah di Kota Makassar dengan menganalisis atribut-atribut inovasi yang digunakan dalam menilai pelaksanaan inovasi. Penelitian ini dilaksanakan di wilayah kota Makassar sebagai tempat penerapan pelaksanaan program smart card sebagai pendukung terciptanya smart city di kota Makassar sehingga dijadikan sebagai fokus utama penelitian dalam menggali informasi serta mendapatkan gambaran akan penerapan program inovasi ini. Penelitian yang digunakan adalah deskriptif dengan pendekatan kualitatif, Untuk memperdalam analisis data maka dilakukan wawancara secara mendalam (Indepth Interview) dengan teknik penentuan informan dilakukan secara Purposive Sampling dan pendalaman informasi dalam penelitian ini berkembang mengikuti informasi yang ada atau data yang dibutuhkan (snowball), Penelitian ini di fokuskan pada pelaksanaan program Smart Card sebagai inovasi pemerintah daerah di kota Makassar berdasarkan Undang-Undang No. 23 Tahun 2014 Tentang Pemerintahan Daerah dan atribut inovasi yang dijadikan sebagai ukuran pelaksanaan inovasi pemerintahan daerah.

Hasil penelitian menunjukkan bahwa Pelaksanaan program smart card berdasarkan prinsip Undang-Undang No. 23 Tahun 2014 Tentang Pemerintahan Daerah dilihat dari prinsip Peningkatan Efisiensi; Perbaikan Efektifitas; Perbaikan Kualitas Pelayanan; Tidak ada konflik kepentingan; Berorientasi kepada kepentingan umum; Dilakukan secara terbuka; Memenuhi nilai-nilai kepatutan; Dapat dipertanggungjawabkan hasilnya tidak untuk kepentingan diri sendiri. Dan artibut inovasi sebagai ukuran untuk menilai pelaksanaan inovasi pemerintah daerah yaitu : Relative Advantage atau Keuntungan Relatif, Compatibility atau Kesesuaian, Complexity atau Kerumitan, Triability atau Kemungkinan dicoba, Observability atau Kemudahan diamati semua berjalan dengan baik.

Kata Kunci : Inovasi Pemerintah Daerah, Smart City, Smart Card.
\end{abstract}

\section{LATAR BELAKANG PENELITIAN}

Pemerintah daerah saat ini dituntut untuk melakukan pembaharuan diberbagai sektor sebagai suatu langkah untuk mengatasi tuntutan masyarakat yang semakin kompleks. Inovasi menjadi suatu keharusan yang mesti dilakukan agar keberadaan pemerintah menjadi bermakna di mata rakyatnya (van Vierlo, 1996). Inovasi tidak hanya penting untuk meningkatkan pelayanan tetapi juga untuk meningkatkan kapabilitas 
pemerintah (Nutt and Backoff, 1993; Miller and Friesen, 1983; Osborne and Gaebler, 1992).Keberadaan pemerintah daerah di mana pun juga adalah dimaksudkan uintuk menghasilkan output. Output penyelenggaraan pemerintahan oleh daerah adalah berupa percepatan kesejahteraan masyarakat yang dicapai melalui pemberdayaan masyarakat, peran serta masyarakat, dan peningkatan daya saing daerah. Oleh karena itu inovasi kelembagaan atau inovasi dalam bidang organisasi menjadi penting dalam praktek pennyelenggaraan pemerintahan daerah (Fadel Muhammad : 2004).

Perkembangan teknologi yang semakin pintar membuat konsep smart tak hanya diterapkan pada berbagai perangkat, tetapi pada berbagai system atau tatanan.Salah satunya yang mencuat akhir-akhir ini adalah konsep smart city. Konsep yang disebut sebagai kota pintar ini adalah konsep yang mengetengahkan sebuah tatanan kota cerdas yang bisa berperan dalam memudahkan masyarakat untuk mendapatkan informasi secara cepat dan tepat. Selain itu, konsep kota pintar ini juga memang dihadirkan sebagai jawaban untuk pengelolaan sumber daya secara efisien. Bisa dibilang, konsep kota cerdas ini adalah integrasi informasi secara langsung dengan masyarakat perkotaan. Kota-kotabesar di Indonesia sebenarnya sangat berpotensi besar terhadap gagasan atau konsep Smart City, beberapa kota besar yang sudah mengarah tentang konsep smart city ini atara lain : Jakarta, Bandung, Surabaya, Bogor. Modal dari kota-kota ini terbilang sudah mewakili untuk arah yang dimaksud. Apalagi ditopang dengan banyaknya sarana penunjang dan dibantu operator selular akan mempercepat tercapainya sebuah kota untuk menuju smart city dalam arti sesungguhnya, bukan hanya pintar dalam kecanggihan teknologi, namun bagaimana mengedepankan sosiobudaya akan beriringan dengan kemajuan kota itu sendiri (Sudaryono :2014).

Secara umum Inovasi memiliki atribut yang digunakan dalam menilai Inovasi yaitu : Relative Advantage atau Keuntungan Relatif, Compatibility atau Kesesuaian, Complexity atau Kerumitan, Triability atau 
Kemungkinan dicoba, Observability atau Kemudahan diamati, Dengan atribut seperti ini maka sebuah inovasi merupakan cara baru menggantikan cara lama dalam mengerjakan atau memproduksi sesuatu. Namun demikian, inovasi mempunyai dimensi geofisik yang menempatkannya baru pada satu tempat, namun boleh jadi merupakan sesuatu yang lama dan biasa terjadi di tempat lain (Roggers: 2003).

Semakin hari di beberapa wilayah di dunia sudah mengalami urbanizing, seluruh wilayah di dunia sudah semakin 'mengkota'. Urbanisasi tidak dapat dicegah, walaupun menimbulkan masalah baru di kota, masalah ini harus dipecahkan melalui teknologi. Namun kota yang sudah mengadopsi program Smart City, harus lebih meningkatkan di aspek penting lain. Smartcity hanyalah buzzword, Smartcity bukan hanya soal teknologi (Wicaksono Sarosa :2015).

Adapun penelitian yang telahdilakukansebelumnya terkait dengan penelitian ini yaitu Dini Ardilla (2015) peneliti Smart City Products \& Innovations Lembaga Pengembangan Inovasi dan Kewirausahaan (LPIK) ITB, dimana meneliti mengenai Pelaksanaan Smart City di Kota Bandung, hasil penelitiannya menunjukkan bahwa Kota Bandung masih jauh bila ingin disebut 'Smart City' walaupun bandung memiliki platform yang bagus, memiliki sistem operasi yang bagus, tetapi manfaatnya belum dirasakan secara umum oleh masyarakat.Selain penelitian yang dilakukan oleh Irfani Ahmad dan Marini Wulandari (2015) dengan penelitian mengenai Kelembagaan e-Government sebagai Pendukung Smart Governance dimana hasil penelitiannya menunjukkan bahwa Untukmewujudkan kelembagaan e-Governmentyang efektif dan efisien pemerintah diharapkan membentuk kelembagaan yang khusus mengelola pengembangan e-Government yang nantinya akan membantu sebuah kota dalam mendukung mewujudkan smart governance.

Walikota Makassar memperkenalkan langkah pemerintah kota untuk memudahkan pemantauan aktivitas warga yang semakin memadati Kota Makassar. Danny Pomanto perkenalkan Makassar Smart Card sebagai kartu yang dapat digunakan untukkartu transaksi segala 
kebutuhan warga, one card for all. Bekerja sama dengan salah satu bank swasta, kartu ini diharapkan menjadi alat transaksi yang aman, menjadi penyimpan data kependudukan dan pegawai pemerintahan, serta dapat digunakan sebagai penyimpan data aktivitas medis dan pajak. Kartu ini juga sebagai dukungan terhadap program Bank Indonesia, yaitu Less Cash Society yang lebih efisien dalam bertransaksi dibandingkan alat transaksi tunai.Setelah seluruh masyarakat sudah memiliki kartu ini. Makassar Smart Card yang dikhususkan untuk anak-anak dan pelajar, kartu khusus ini bukan hanya digunakan untuk transaksi, tetapi melalui kartu ini juga orang tua dapat mengatur jumlah biaya yang dibutuhkan anak per bulan, memantau transaksi jual-beli dan memantau posisi anak dan waktu sekolah anak hanya dengan menggunakan PC ataupun smartphone berbasis Android (Kompasiana: 8 Juni 2015). Namun masalah yang timbul adalah ketika tidak validnya pendataan seperti pandangan dari Ketua Komisi VIII DPR RI, Saleh Partaonan Daulay dimana mengatakan bahwa "jika program ini tidak tepat sasaran, sama saja tidak memeberikan manfaat. Misalnya beberapa daerah persoalan pendataan yang tidak akurat. Ada orang yang seharusnya tidak dapat justru dapat, begitupun sebaliknya"(Inspirasi, 6 Februari 2015). Inilah yang mendorong penulis untuk melakukan penelitian dengan Judul "Inovasi Pemerintah Daerah dalam Pelaksanaan Program Smart Card di Kota Makassar".

\section{RUMUSAN MASALAH PENELITIAN}

Berdasarkan uraian latarbelakang, selanjutnya dirumuskan permasalahan pokok dalam penelitian yaitu, "Bagaimana Pelaksanaan Program Smart Card sebagai Inovasi Pemerintah Daerah di Kota Makassar?

\section{MAKSUD DAN TUJUAN PENELITIAN}


Penelitian ini bertujuan untuk mengetahui Bagaimana Pelaksanaan Program Smart Card sebagai Inovasi Pemerintah Daerah di Kota Makassar dengan menganalisis atribut-atribut inovasi yang digunakan dalam menilai pelaksanaan inovasi.

\section{KEGUNAAN PENELITIAN}

1. Hasil penelitian ini dapat digunakan dalam pengembangan teori khususnya inovasi pemerintah daerah.

2. Hasil penelitian ini dapat menjadi bahan informasi dan referensi bagi peneliti lain yang berminat mengadakan penelitian pada bidang yang sama dalam rangka pengembangan inovasi pemerintah daerah dalam segala bidang.

3. Kegunaan praktis. Hasil penelitian ini dapat memberikan konstribusi atau masukan bagi pemerintah kota makassar dalam upaya menciptakan serta melaksanakan inovasi pemerintah daerah khususnya terkait dengan pelaksanaan Smart Card City dan inovasi dalam segala bidang.

\section{KAJIAN PUSTAKA}

\section{Inovasi Pemerintah Daerah}

Albury (dalam Yogi Suwarno, $2008: 23$ ) secara lebih sederhana mendefinisikan inovasi sebagai new ideas that work. Ini berarti bahwa inovasi adalah berhubungan erat dengan ide-ide baru yang bermanfaat. Inovasi dengan sifat kebaruannya harus mempunyai nilai manfaat. Selanjutnya Albury secara rinci menjelaskan bahwa ciri dari inovasi yang berhasil adalah adanya bentuk penciptaan dan pemanfaatan proses baru, produk baru, jasa baru dan metode penyampaian yang baru, yang menghasilkan perbaikan yang signifikan dalam hal efisiensi, efektivitas maupun kualitas.

Menurut Metcalfe (dalam Erni Zuhriyati dkk, 2012 : 9) inovasi merupakan sistem yang menghimpun institusi - institusi berbeda yang berkontribusi, secara bersama maupun individu, dalam pengembangan 
dan difusi teknologi - teknologi baru dan menyediakan kerangka kerja (framework) di mana pemerintah membentuk dan mengimplementasikan kebijakan - kebijakan untuk mempengaruhi proses inovasi. Dengan demikian, sistem inovasi merupakan suatu sistem dari lembaga - lembaga yang saling berkaitan untuk menciptakan, menyimpan, dan mengalihkan (mentransfer) pengetahuan, keterampilan yang menentukan teknologi baru. Inovasi tidak akan bisa berkembang dalam kondisi status quo. Inovasi mempunyai satu sifat mendasar yaitu sifat kebaruan. Sifat kebaruan ini merupakan ciri dasar inovasi dalam menggantikan pengetahuan, cara, objek, teknologi atau penemuan yang lama, yang sudah tidak efektif dalam menyelesaikan suatu masalah walaupun tidak ada satu kesepahaman definisi mengenai inovasi, namun secara umum dapat disimpulkan bahwa inovasi mempunyai atribut yang dapat dijadikan ukuran untuk menilai pelaksanaan inovasi (Rogers dalam Yogi Suwarno, 2008 : 17) yaitu:

\section{Relative Advantage atau Keuntungan Relatif}

Sebuah inovasi harus mempunyai keunggulan dan nilai lebih dibandingkan dengan inovasi sebelumnya. Selalu ada sebuah nilai kebaruan yang melekat dalam inovasi yang menjadi ciri yang membedakannya dengan yang lain.

\section{Compatibility atau Kesesuaian}

Inovasi juga mempunyai sifat kompatibel atau kesesuaian dengan inovasi yang digantinya. Hal ini dimaksudkan agar inovasi yang lama tidak serta merta dibuang begitu saja, selain karena alasan faktor biaya yang tidak sedikit, namun juga inovasi yang lama menjadi bagian dari proses transisi ke inovasi terbaru. Selain itu juga dapat memudahkan proses adaptasi dan proses pembelajaran terhadap inovasi itu secara lebih cepat.

\section{Complexity atau Kerumitan}

Dengan sifatnya yang baru, maka inovasi mempunyai tingkat kerumitan yang boleh jadi lebih tinggi dibandingkan dengan inovasi sebelumnya. Namun demikian, karena sebuah inovasi menawarkan cara yang lebih baru dan lebih baik, maka tingkat kerumitan ini pada umumnya tidak menjadi masalah penting.

\section{Triability atau Kemungkinan dicoba}

Inovasi hanya bisa diterima apabila telah teruji dan terbukti mempunyai keuntungan atau nilai lebih dibandingkan dengan inovasi yang lama. Sehingga sebuah produk inovasi harus melewati fase "uji publik", dimana setiap orang atau pihak mempunyai kesempatan untuk mengujii kualitas dari sebuah inovasi.

\section{Observability atau Kemudahan diamati}


Sebuah inovasi harus juga dapat diamati, dari segi bagaimana ia bekerja dan menghasilkan sesuatu yang lebih baik.

Sedangkan strategi inovasi dalam pemerintahan menurut Sangkala (2013 : 38) yaitu:

a. Layanan terintegrasi, dimana sektor publik menawarkan peningkatan sejumlah layanan, warga memiliki harapan yang tidak sederhana dimana warga meminta layanan yang disediakan disertai dengan kenyamanan.

b. Desentralisasi pemberian dan monitoring layanan lebih dekat dengan masyarakat dan biasanya membentuk kepastian tehadap tingkat permintaan yang tinggi sehingga meningkatkan kepuasan masyarakat atau pelaku bisnis.

c. Pemanfaatan kerjasama, bermakna sebagai pemerintahan yang inovatif untuk memenuhi peningkatan pemenuhan agar lebih efisien dalam pemberian layanan publik, lebih kolaboratif antar organisasi dan juga terjadi kerjasama antara publik dan swasta.

d. Pelibatan warga Negara.Kewenangan pemerintah yang Inovatif harus merealisasikan peran peran pentingnya dengan mendorong peran warga untuk berpartisipasi dalam mendorong perubahan.

e. Pemanfaatan teknologi komunikasi dan informasi.

\section{Smart City}

Smart city adalah konsep perencanaan kota dengan memanfaatkan perkembangan teknologi yang akan membuat hidup yang lebih mudah dan sehat dengan tingkat efisiensi dan efektifitas yang tinggi. Beberapa para ahli menganggap konsep kota dengan smart city dapat memenuhi kebutuhan akan kemudahan hidup dan kesehatan, walaupun pada kenyataannya konsep smart city masih dalam perdebatan oleh para ahli dan belum ada defenisi dan konsep umum yang bisa diterapkan di semua kota didunia. Konsep smart city masih bergantung pada kota dan pengembang masing-masing (Hendro, 2015 : 2).

Beberapa para ahli mencoba mendifenisikan smart city dengan defenisi masing-masng berdasarkan bidang keilmuan masing-masing, antara lain menurut Caragliu, A., dkk (dalam Schaffers, 2010 : 3) Smart City didefinisikan juga sebagai kota yang mampu menggunakan SDM, modal sosial, dan infrastruktur telekomunikasi modern untuk mewujudkan pertumbuhan ekonomi berkelanjutan dan kualitas kehidupan yang tinggi, dengan manajemen sumber daya yang bijaksana melalui pemerintahan 
berbasis partisipasi masyarakat sedangkan menurut Jung Hoon (dalam Hendro, 2015 : 3) Smart city merupakan kota dengan investasi modal manusia dan sosial, dengan transportasi (tradisonal) dan infrastruktur komunikasi modern serta pembangunan ekonomi yang berkelanjutan dan kualitas hidup yg tinggi, dengan manajemen SDA yang bijaksana melalui tata pemerintahan yang partisipatif.

Kota cerdas atau smart city, pada umumnya didasarkan pada 3 hal, pertama faktor manusia, kota dengan manusia-manusia yang kreatif dalam pekerjaan, jejaring pengetahuan, lingkungan yang bebas dari criminal. Kedua faktor teknologi, kota yang berbasis teknologi komunikasi dan informasi. Terakhir faktor kelembagaan, masyarakat kota (pemerintah, kalangan bisnis dan penduduk) yang memahami teknologi informasi dan membuat keputusan berdasarkan pada teknologi informasi (Ahmad Nurmandi, 2014 : 400). Salah satu ahli smart city, Boyd Cohen mencoba membagi smart city ke dalam enam indikator utama, yaitu :
1. Smart People;
2. Smart Environment;
3. Smart Living;
4. Smart Mobility;
5. Smart Ekonomi;
6. Smart Governance

Sedangkan Giffinnger dan Cohehen (dalam Hendro, 2015: 7) menjelaskan bahwa dalam perwujudan suatu konsep smart city dalam implementasi terhadap 6 sumbu tersebut, diperlukan suatu tolak ukur yang menghitung mengenai keberadaan smart city.

1) Smart Living atau hidup yang cerdas : yaitu mengacu pada kualitas hidup dan kebudayaan masyarakat faktor yang paling mempengaruhi adalah tersedianya kebutuhan-kebutuhan, adanya keamanan, keselamatan, kemudahan dan kenyamanan hidup.

2) Smart Governance atau tata kelola pemerintahan yang cerdas : paradigma pemerintahan yang mengeluarkan kebijakan yang mengindahkan prinsip-prinsip supremasi hukum, kemanusiaan, keadilan, demokrasi, partisipasi, transparansi, profesionalitas, dan akuntabilitas serta efektifitas dan efesiensi kebijakan.

3) Smart Economy atau Ekonomi cerdas : yaitu tingginya tingkat perekonomian dan kesejahteraan finansial masyarakat dengan pertumbuhan ekonomi yang baik dan pendapatan perkapita yang tinggi. 
4) Smart Mobility atau Mobilitas cerdas : yaitu sistem pergerakan yang memungkinkan terjadinya pemenuhan kebutuhan dengan pergerakan seminim mungkin dan secepat mungkin.

5) Smart Environment atau Lingkungan cerdas : yaitu lingkungan yang memberikan kenyamanan dimasa kini dan masa mendatang dengan kata lain keberlanjutan lingkungan baik keadaan fisik maupun non fisik.

6) Smart People atau Masyarakat cerdas : yaitu modal manusia yang weel educated baik secara formal maupun non formal dan terwujud dalam individu atau komunitas-komunitas yang kreatif.

\section{SMART CARD}

SMART Card sering disebut sebagai chip card atau integrated circuit (IC) card. Definisi chip card sendiri yaitu kategori umum yang mencakup smart card dan memory card. Smart card adalah plastic card yang mengandung memory chip dan microprocessor. Kartu ini bisa menambah, menghapus, mengubah informasi yang terkandung. Keunggulan smart card tidak perlu mengakses database di server karena sudah ada sebagian di kartu. Sedangkan memory card dipasangi memory silicon tanpa microprocessor. Fungsi dasar suatu smart card adalah untuk mengidentifikasi card holder ke sistem komputer. Cardholder disini adalah pemilik asli kartu tersebut Identifikasi ini menyangkut otentifikasi organisasi yang membuat kartu tersebut dan cardholder serta hak aksesnya. (Dwi Apriyani, 2008).

Transaksi adalah bagian dari kehidupan manusia yang paling esensial. la muncul hampir seumur peradaban manusia itu sendiri. Namun yang membedakan manusia sangat unik sebagai mahluk ekonomi adalah, manusia mampu menjadikan dirinya sebagai subyek sekaligus obyek dari transaksi pada saat bersamaan. Itulah sebabnya, proses perbaikan sistem transaksi selalu beriringan dengan kebutuhan manusia untuk memudahkan kehidupannya. Berbekal prinsip itu, maka bisa dipahami mengapa negara melalui Otoritas Jasa Keuangan dan Bank Indonesia memandang perlu untuk memasyarakatkan program Less Cash Society atau masyarakat yang gemar bertransaksi non-tunai atau bertransaksi dengan uang berfisik. Langkah yang sangat bagus dilakukan oleh BRI bekerjasama dengan Kota Makassar dengan melaunching Makassar 
Smart Card. Smart Card yang merupakan kerjasama Pemerintah Kota Makassar dan BRI, menggabungkan dua fungsi utama yakni sebagai basis data (data base) dan alat transaksi. Basis data itu mencakup Nomor Induk Kependudukan, Nomor Induk Pegawai, Nomor Pokok Wajib Pajak, dan rekam jejak kesehatan (medical record). Sedangkan pada fungsi pembayaran mencakup fungsi dasar dari Kartu Brizzi (kartu e-money), kartu ATM, dan pembayaran kebutuhan lain. Pemerintah Kota Makassar dan BRI menegaskan, pengembangan kedua fungsi itu masih terbuka lebar, sesuai kebutuhan (Kompasiana.com, 2015).

\section{OBJEK DAN METODE PENELITIAN \\ Pendekatan Dan Jenis Penelitian}

Penelitian yang digunakan adalah deskriptif dengan pendekatan kualitatif. Bodgan dan Taylor dalam Moleong (2007:4) mendefinisikan metedologi kualitatif sebagai "prosedur penelitian yang menghasilkan data deskriptif, berupa kata-kata tertulis atau lisan dari orang-orang dan perilaku yang dapat diamati".

\section{Lokasi Penelitian}

Penelitian ini dilaksanakan di wilayah kota Makassar sebagai tempat penerapan pelaksanaan program smart card sebagai pendukung terciptanya smart city di kota Makassar sehingga dijadikan sebagai fokus utama penelitian dalam menggali informasi serta mendapatkan gambaran akan penerapan program inovasi ini.

\section{Sumber Data}

Data-data penelitian diperoleh dari berbagai sumber data guna menjawab permasalahan penelitian, yaitu :

a. Data Primer, diperoleh melalui observasi sangat mendalam, dan wawancara mendalam (in depth interview) dengan masyarakat, dan pihak yang berwenang untuk memberikan informasi dan keterangan mengenai pelaksanaan program smart card sebagai inovasi pemerintah daerah di kota Makassar. 
b. Data Sekunder, diperoleh melalui telaah dokumentasi secara jeli yang bersumber pada literatur dokumen-dokumen atau tulisan-tulisan serta studi-studi penelitian yang sejenis yang ada hubungannya dengan permasalahan penelitian.

\section{INFORMAN PENELITIAN}

Untuk memperdalam analisis data yang berkaitan dengan pelaksanaan program smart card sebagai inovasi pemerintah daerah di kota Makassar, maka dilakukan wawancara secara mendalam dengan informan dari Pegawai Negeri Sipil (PNS) dan Pelajar dan masyarakat umum sebagai bagian dari Masyarakat kota Makassar yang menjadi sasaran utama pelaksanaan program smart card yang berdomisili di wilayah kota Makassar dengan Teknik penentuan informan dilakukan secara Purposive Sampling dimana penentuan sampel dalam penelitian ini tidak dilakukan pada seluruh populasi, tapi terfokus pada target. Purposive Sampling artinya bahwa penetuan sampel mempertimbangkan kriteria-kriteria tertentu yang telah dibuat terhadap obyek yang sesuai dengan tujuan penelitian. Dimana dalam penelitian ini penentuan sampel yang dilakukan harus sesuai fokus utama pada wilayah tempat pelaksanaan program smart card mengingat program ini masih dalam tahap pengembangan. Adapun jumlah sampel sebanyak 30 orang. Namun demikian, pendalaman informasi dalam penelitian ini berkembang mengikuti informasi yang ada atau data yang dibutuhkan (snowball), sehingga memungkinkan melibatkan pihak pemerintah kota dalam hal ini Dinas Informasi dan Komunikasi Kota Makassar.

\section{ANALISIS DATA}

Dalam peneltian ini, setelah mendapatkan data dibutuhkan, selanjutnya diolah menggunakan teknik analisa data kulaitatif dengan jalan mengabstrksikan secara cermat setiap informasi yang diperoleh. Analisa ini diharapkan mampu memberikan pemahaman yang utuh dan mendalam terhadap interaksi atau konsep-konsep yang akan diteliti. 
Sehubungan penelitian ini akan menjawab permasalahan yang berkenaan dengan kualitas pelayanan pada kantor perijinan, faktor-faktor yang melatarbelakangi dan memetakan realitas problematis yang ada maka dengan analisis yang bersifat deskriptif kualitatif segera dilakukan setelah melakukan wawancara, meghimpun data sekunder maupun literatur, dan sumber-sumber lainnya terkumpul secara lengkap.

Studi lapangan dilakukan untuk mendapatkan data primer dan sekunder. Data primer dilakukan melalui metode wawancara, observasi atau pengamatan. Sedangkan data sekunder diperoleh dari dokumendokumen yang dapat memperjelas data primer. Dalam kaitan ini, peneliti juga melakukan studi dokumen yang dimaksudkan untuk memperoleh informasi berkaitan pelaksanaan program Smard Card sebagai Inovasi Pemerintah Daerah di Kota Makassar. Dengan demikian dari studi dokumen tersebut diperoleh gambaran jelas mengenai isi dan substansi pelaksanaan program tersebut di Kota Makassar. Sementara itu metode wawancara yang digunakan adalah metode wawancara secara tak berstruktur, yaitu peneliti mengajukan pertanyaan-pertanyaan secara lebih bebas dan leluasa tanpa terikat oleh susunan pertanyaan yang telah dipersipkan secara kaku, selain itu dapat berkembang sesuai dengan kebutuhan penelitian. Proses selanjutnya data yang telah terkumpul akan diseleksi dan diklsifikasikan sesuai dengan kebetuhan analisis. Sehubungan dengan hal tersebut data dan informasi yang telah berhasil diperoleh dan diklasifikasi kemudian dianalisis berdasarkan perspektif kerangka pemikiran yang digunakan. Adapun pengolahan data dilakukan dengan cara :

1. Melakukan observasi seluruh data yang tersedia dari berbagai sumber, yaitu dari hasil penelitian dan studi-studi pustaka yang berkenaan dengan pelaksanaan Inovasi Pemerintah Daerah.

2. Menginterprestasikan gejala dan temuan penelitian, berdasarkan temuan, pengetahuan dan pengalaman. 
Kemudian dalam melakukan analisa, terdapat tiga alur kegiatan yang dilakukan secara bersamaan dan menjadi suatu siklus serta interaksi antara alur yang satu dengan alur yang lainnya yaitu :

1. Reduksi data, yaitu proses pemilihan, perumusan, atau perhatian pada penyederhanaan, pengabstrakan dan transformasi data kasar yang muncul dari catatan tertulis di lapangan dimana proses ini berlangsung secara terus menerus selama penelitian berlangsung.

2. Penyajian data, merupakan sekumpulan informasi yang telah tersusun secara terpadu dan mudah dipahami dan memberikan kemungkinan dilakukannya penarikan kesimpulan dan pengambilan tindakan, penyajian data ini menuntut soerang peneliti untuk mampu mentransformasikan data kasar menjadi bentuk tulisan.

3. Verifikasi atau penarikan kesimpulan merupakan sebagian dari seluruh konfigurasi kegiatan penelitian yang utuh dan dapat dilakukan selama penelitian berlangsung, verifikasi ini mungkin sesingkatnya saja. Kemudian pemikiran yang kembali melintas dalam pikiran peneliti selama ini adalah menulis dan meninjau ulang catatan-catatan lapangan, dimana memakan waktu dan tenaga yang lebih besar. Analisis data dilakukan berdasrkan pada pendekatan kualitatif yang menitikberatkan pada penelitian yang bersifat deskriptif terhadap data-data yang berasal dari hasil wawancara dan observasi (pengamatan). Dari keabsahan data yang telah didapatkan tersebut maka dilakukan pemeriksanaan dan diverifikasi sesuai dengan keperluan penelitian. Untuk memeriksa keabsahan data dilakukan triangulasi yang memanfaatkan sesuatu yang lain diluar data untuk keperluan pengecekan atau sebagai pembanding terhadap data itu. Triangulasi dengan sumber berarti membandingkan dan mengecek balik derajat kepercayaan suatu informasi yang diperoleh melalui waktu dan alat yang berbeda dalam metode kualitatif. 


\section{HASIL PENELITIAN DAN PEMBAHASAN}

Tantangan Pemerintah Daerah yang semakin luas dan penuh persaingan, memposisikan pemerintahan yang baik (Good Governance) sebagai dambaan bagi semua Negara, terkhusus di Indonesia. Tujuan ini dibuktikan dengan semakin inovatifnya pemerintah kabupaten/kota dalam melaksanakan pemerintahan melalui fokus pada pemanfaatan teknologi dan inovasi. Berbagai upaya dan studi telah dilakukan, seperti studi EPemerintahan serta inovasi pemerintahan yang berdasar pada pendekatan baru yang smart dan ramah teknologi dengan tujuan mewujudkan kota yang lebih cerdas, dimana mampu melayani dan menciptakan kota yang nyaman untuk hidup bagi warganya, kota yang lebih cerdas ini dikenal dengan istilah smart city.

Salah satu kesiapan dalam berkompetisi dan memberikan pelayanan terbaik ini, dengan begitu massifnya beragam inovasi yang dihasilkan oleh pemerintah daerah, tidak terkecuali Kota Makassar, sebagai jembatan yang menghubungkan antara zona barat Indonesia dan zona timur Indonesia, sekaligus sebagai pintu masuk ke Kawasan Timur Indonesia, dengan segala keunggulan sumber daya alam dan sumber daya manusia yang siap berkompetisi, adalah dengan dihadirkannya inovasi Smart City atau dalam konsep besar yang dirancang oleh Pemerintah Kota Makassar, akan terbangun satu kota yang hadir dengan wajah dan gerak Smart dan Sombere' City, sebagaimana tertuang dalam RPJMD Kota Makassar tahun 2014-2019. Sadar akan hal itu maka dikeluarkanlah smart card sebagai sebuah bentuk pelayanan transaksi baru yang disediakan oleh Pemerintah Kota Makassar dalam mengakses setiap fasilitas pelayanan baik itu pendidikan, kesehatan, transportasi, ekonomi, birokrasi, serta fasilitas lainnya.

Adapun hasil penelitian terkait dengan inovasi pemerintah daerah dalam pelaksanaan program smart card Inovasi daerah sebagaimana yang termaktub dalam Undang-Undang No. 23 Tahun 2014 Tentang Pemerintahan Daerah BAB XXI Pasal 387 menjelaskan bahwa dalam 
merumuskan kebijakan inovasi, pemerintahan daerah mengacu pada prinsip :

\section{Peningkatan Efisiensi;}

Inovasi pemerintah Kota Makassar dalam hal ini Smart Card diharapkan dapat meningkatkan efisiensi pekerjaan yang dilakukan pemerintah dan masyarakat, dalam hal ini Program smart card dapat menciptakan suatu kondisi atau keadaan, dimana penyelesaian suatu pekerjaan dilaksanakan dengan benar dan dengan penuh kemampuan yang dimiliki, tanpa harus menimbulkan keborosan. Terkait dengan Efisiensi pelaksanaan program smart card, berdasarkan penjelasan baik dari pihak mitra kerja maupun dari pemerintah sendiri menunjukkan bahwa efisiensi dapat dikatakan terwujud sebab dana yang dipakai disesuaikan dengan porsi kebutuhan proyek apalagi di tunjang dengan infrastruktur yang sangat memadai yang telah dipersiapkan BRI sebagai mitra kerja pemerintah, bukan itu saja efisiensi juga terwujud dari tidak dipungutnya biaya dalam pengurusan kartu sehingga penggunaan sumber daya sesuai dengan porsi kebutuhan dalam pelaksanaan smart card di Kota makassar.

\section{Perbaikan Efektifitas;}

Inovasi pemerintah Kota Makassar dalam hal ini Smart Card diharapkan dapat memperbaiki sisi efektifitas yang ada, perbaikan efektifitas dari efek keberadaan Smart Card ini dapat menciptakan suatu kondisi atau keadaan, dimana dalam memilih tujuan yang hendak dicapai dan sarana atau peralatan yang digunakan, disertai tujuan yang diinginkan dapat dicapai dengan hasil yang memuaskan bagi Kota Makassar. Terkait kesesuaian pelaksanaan program smart card dengan tujuan yang ingin dicapai yaitu memberikan kepuasan bagi masyarakat di kota Makassar dimana pelaksanaan program smart card berdasarkan analisis peneliti maka dapat dikatakan sangat memberikan kepuasaan bagi masyarakat sebab berkat adanya smart card ini memberikan solusi terkait dengan masalah birokrasi yang berbelit-belit, bukan hanya itu saja kemudahankemudahan juga dapat dilihat dari dijadikannya kartu smart card sebagai kartu untuk tabungan, transaksi pembayaran dan bahkan dijadikan kartu 
untuk menampung pendistribusian tunjangan sehingga tidak perlu lagi untuk mengantri di bank". Secara keseluruhan kepuasaan sangat dirasakan oleh masyarakat ditunjukkan dengan adanya kemudahankemudahan tersebut sesuai dengan tujuan peruntukannya sebagai kartu yang memberikan segala kemudahan.

\section{Perbaikan Kualitas Pelayanan;}

Inovasi Pemerintah Kota Makassar dalam hal ini Smart Card diharapkan dapat memperbaiki kualitas pelayanan pemerintahan yang pernah berjalan, apalagi Program Smart Card ini mengusung keunggulan teknologi dalam pelayanan pemerintah terhadap masyarakat, sehingga tentunya inovasi ini merupakan titik balik dari perbaikan kualitas pelayanan yang maju, cepat, tepat, serta berkeunggulan. Terkait dengan pelaksanaan program smart card dalam menciptakan pelayanan berkualitas peneliti menyimpulkan bahwa hal tersebut tercapai dengan baik, hal ini terlihat dari perubahan proses pelayanan yang dulunya membutuhkan proses yang panjang dengan adanya program smart card hal tersebut menjadi lebih sederhana, dan bukan hanya itu saja transparansi dalam pelayanan juga dapat terwujud sebab segala proses pelayanan dilakukan dan diawasi oleh kita sendiri sehingga lebih diketahui akan peruntukan dari kartu smart card sesuai dengan peruntukannya.

\section{Tidak ada konflik kepentingan;}

Diharapkan dengan kehadiran inovasi Pemerintah Kota Makassar berupa program Smart Card ini, tidak timbul konflik kepentingan, uamanya dalam persoalan penyediaan dan implementasi program, pengawasan serta evaluasi program. Dengan kehadiran inovasi baru ini, dapat terbangun relasi yang baik antar Stakeholder dalam mewujudkan visi pemerintahan yang telah ditetapkan dalam RPJMD. Terkait dengan pelaksanaan program smart card hubungannya dengan konflik kepentingan utamanya dalam persoalan penyediaan dan implementasi program, pengawasan serta evaluasi progammenciptakan pelayanan berkualitas peneliti menyimpulkan bahwa dengan adanya dasar hukum 
yang jelas dalam pelaksanaan program ini, dibantu lagi dari pihak pengawas dan tim evaluasi kerja, dapat membantu mengurangi peluang kecurangan dalam implementasi program smart card ini.

\section{Berorientasi kepada kepentingan umum;}

Inovasi Pemerintah Kota Makassar, berupa program Smart Card ini, berkewajiban berorientasi kepada kepentingan umum, sesuai dasar upaya perwujudan program Smart Card ini, yaitu bagaimana program ini menciptakan kenyamanan. Terkait dengan pelaksanaan program smart card dalam orientasi kepada kepentingan umum yaitu menciptakan kenyamanan peneliti menyimpulkan bahwa harapan pemerintah kota Makassar telah sampai ke masyarakat, yaitu masyarakat merasakan manfaat positif dari pelaksanaan program ini, masyarakat sangat merasakan kenyamanan dan sangat terbantu dengan hadirnya program tersebut.

\section{Dilakukan secara terbuka;}

Terkait dengan transparansi kepada semua pihak yang berkepentingan dalam program smart card dari seluruh jawaban baik masalah Perencanaan, implementasi, pengawasan dan evaluasi dari Inovasi pemerintah Kota Makassar berupa program Smart Card ini dilakukan secara terbuka maka peneliti dapat menarik kesimpulan bahwa hal tersebut berjalan dengan baik bahkan maasyarakatpun mengerti akan proses keterbukaan yang berusaha disampaikan oleh pihak pemerintah kota makassar, keterbukaan serta transparansi dilihat dari sistem elektronifikasi yang diterapkan pada semua sektor termasuk penerimaan pajak dan retribusi, target wajib dan transaksi kepada pihak ketiga, dan pembayaran honorarium pegawai itu semua sudah menunjukkan keterbukaan dan bukan hanya itu saja OJK dan BI pun ikut andil dalam mengawasi pelaksanaan program smart card ini.

\section{Memenuhi nilai-nilai kepatutan;}

Inovasi Pemerintah Kota Makassar dalam hal ini program Smart Card wajib memenuhi nilai-nilai kepatutan yang ada, baik yang dianut oleh Masyarakat Kota Makassar secara khusus maupun Indonesia secara 
umum, sebagaimana yang diatur oleh undang-undang dan peraturan pemerintah lainnya. Peneliti dapat menyimpulkan bahwa pelaksanaan program smart card sudah memenuhi nilai dan kaidah yang jelas sebab sudah melalui kajian yang mendalam dan bahkan sudah ada sosialisasi yang dilakukan pemerintah dibarengi dengan pelaksanaan yang menyesuaikan data penduduk bukan hanya itu saja hal tersebut juga disesuaikan dengan kebutuhan-kebutuhan masyarakat.

\section{Dapat dipertanggungjawabkan hasilnya tidak untuk kepentingan} diri sendiri.

Inovasi Pemerintah Kota Makassar dalam hal ini program smart card diharapkan dapat dipertanggungjawabkan oleh setiap stakeholder, sebagaimana yang telah ditetapkan, sehingga akan dapat berefek baik pada pembangunan program Smart Card, dan program-program unggulan yang akan dikeluarkan pemerintah kelak. Berdasarkan seluruh jawaban responden maka peneliti berkesimpulan bahwa akuntabilitas dalam pelaksanaan program sudah baik namun perlu ditingkatkan terkait dengan penyampaian informasi ke masyarakat baik melalui media online maupun penyampaian secara terbuka yang sudah dilakukan oleh bapak walikota makassar.

Inovasi mempunyai atribut yang dapat dijadikan ukuran untuk menilai pelaksanaan inovasi, adapun hasil penelitian terkait hal tersebut

\section{Relative Advantage atau Keuntungan Relatif}

Inovasi pemerintah daerah dalam hal ini program Smart Card Kota Makassar harus mempunyai keunggulan dan nilai lebih dibandingkan dengan inovasi sebelumnya. Selalu ada sebuah nilai kebaruan yang melekat dalam inovasi yang menjadi ciri yang membedakannya dengan yang lain. Pelaksanaan program smart card berdasarkan analisis peneliti maka dapat dikatakan sangat memuat semangat inovasi berkeunggulan dan memiliki nilai lebih dari inovasi sebelumnya. Apalagi di era kekinian, semua pelayanan diharapkan dapat terintegrasi dan memudahkan akses pelayanan tersebut oleh masyarakat. Satu kartu dengan segala kemudahan pelayanan adalah tanda dari respon kemajuan zaman. 
Apalagi inovasi ini sangat mendukung upaya pemerintah dalam reformasi birokrasi, dimana diharapkan dengan adanya kartu ini dapat meminimalisir korupsi yang terjadi dikalangan birokrat pemerintahan.

\section{Compatibility atau Kesesuaian}

Inovasi pemerintah daerah dalam hal ini program Smart Card Kota Makassar juga mempunyai sifat kompatibel atau kesesuaian dengan inovasi yang digantinya. Hal ini dimaksudkan agar inovasi yang lama tidak serta merta dibuang begitu saja, selain karena alasan faktor biaya yang tidak sedikit, namun juga inovasi yang lama menjadi bagian dari proses transisi ke inovasi terbaru. Selain itu juga dapat memudahkan proses adaptasi dan proses pembelajaran terhadap inovasi itu secara lebih cepat. Peneliti menyimpulkan bahwa program Smart Card ini sebagai jawaban dari tantangan baru pemerintahan yang menuntut inovasi-inovasi yang berkeunggulan dan berkemajuan. Belum lagi oleh Pak walikota mempertegas bahwa pemerintah Kota Makassar senantiasa melakukan upgrade terhadap inovasi-inovasi yang telah dihasilkan, sehingga tidak akan hanya berhenti pada satu inovasi saja. Diharapkan akan ada inovasiinovasi yang terupdate dari inovasi sebelumnya.

\section{Complexity atau Kerumitan}

Dengan sifatnya yang baru, Inovasi pemerintah daerah dalam hal ini program Smart Card Kota Makassar mempunyai tingkat kerumitan yang boleh jadi lebih tinggi dibandingkan dengan inovasi sebelumnya. Peneliti menyimpulkan bahwa memang ada kerumitan yang lebih daripada inovasi sebelumnya, namun yang patut digarisbawahi bahwa kondisi ini merupakan tantangan dari upaya menciptakan inovasi-inovasi yang lebih baik dari sebelumnya. Apalagi kerumitan tersebut dapat dengan baik diselesaikan karena didukung oleh sumber daya manusia yang mumpuni dari perguruan-perguruan tinggi yang unggul di Makassar serta instansi yang senantiasa mendukung program inovasi pemerintah.

\section{Triability atau Kemungkinan dicoba}

Inovasi pemerintah daerah dalam hal ini program Smart Card Kota Makassar telah teruji dan terbukti mempunyai keuntungan atau nilai lebih 
dibandingkan dengan inovasi yang lama. Sehingga harus melewati fase "uji publik", dimana setiap orang atau pihak mempunyai kesempatan untuk mengujii kualitas dari program Smart City ini. Peneliti menyimpulkan bahwa inovasi program Smart card ini telah memberi manfaat bagi masyarakat kota Makassar, walaupun program ini terhitung baru diimplementasikan, namun respon positif telah banyak diterima oleh pemerintah Kota Makassar, apalagi telah diperlihatkan dihadapan pejabat Kanada dengan situasi program ini adalah satu-satunya di dunia, selain itu juga akan diadopsi oleh Bogor dan Tegal, yang menandakan bahwa sudah ada titik keberhasilan dengan kehadiran program kartu ini.

\section{Observability atau Kemudahan diamati}

Inovasi pemerintah daerah dalam hal ini program Smart Card Kota Makassar diamati, dari segi bagaimana ia bekerja dan menghasilkan sesuatu yang lebih baik. Peneliti menyimpulkan bahwa program Smart Card senantiasa mendapatkan pengawasan dari masyarakat, apalagi untuk melancarkan proses evaluasi yang dilakukan masyarakat, pemerintah kota Makassar memiliki akun media sosial untuk menampung keresahan masyarakat terkait program yang telah dikeluarkan pemerintah kota Makassar. Setiap program yang dihasilkan, diinformasikan dengan baik dan diharapkan dapat diketahui, difahami dan dirasakan manfaatnya oleh Masyarakat kota Makassar.

\section{KESIMPULAN DAN REKOMENDASI}

Program Smart Card di Kota Makassar merupakan inovasi terbaru yang dihadirkan oleh pemerintah Kota Makassar dalam merespon persaingan global dan tantangan kota kedepan. Program ini hadir Sebagai sebuah bentuk pelayanan transaksi baru yang disediakan oleh Pemerintah Kota Makassar dalam mengakses setiap fasilitas pelayanan baik itu pendidikan, kesehatan, transportasi, ekonomi, birokrasi, serta fasilitas lainnya. Adapun kesimpulan penelitian terkait dengan Inovasi Pemerintah Daerah dalam pelaksanaan Program Smart Card Kota Makassar yaitu: 
1. Pelaksanaan program smart card berdasarkan prinsip UndangUndang No. 23 Tahun 2014 Tentang Pemerintahan Daerah BAB XXI Pasal 387 dilihat dari prinsip Peningkatan Efisiensi; Perbaikan Efektifitas; Perbaikan Kualitas Pelayanan; Tidak ada konflik kepentingan; Berorientasi kepada kepentingan umum; Dilakukan secara terbuka; Memenuhi nilai-nilai kepatutan; Dapat dipertanggungjawabkan hasilnya tidak untuk kepentingan diri sendiri, semuanya berjalan dengan baik, sehingga dapat disimpulkan bahwa pelaksanaan program smart card sebagai Inovasi pemerintah daerah di Kota Makassar berjalan sesuai dengan prinsip inovasi pemerintah daerah yang telah ditetapkan.

2. Pelaksanaan program smart card berdasarkan artibut inovasi sebagai ukuran untuk menilai pelaksanaan inovasi pemerintah daerah yaitu : Relative Advantage atau Keuntungan Relatif, Compatibility atau Kesesuaian, Complexity atau Kerumitan, Triability atau Kemungkinan dicoba, Observability atau Kemudahan diamati. Semuanya berjalan dengan baik sesuai dengan nilai atribut inovasi yang diharapkan.

Adapun rekomendasi dari hasil penelitian ini adalah :

1. Inovasi ini bisa terus dikembangkan dan dipertahankan sehingga pelayanan publik dapat terus diakses dengan mudah oleh masyarakat kota Makassar.

2. Perlu adanya pengawasan dan evaluasi secara sustainable sehingga proses pelaksanaannya dapat dipertangungjawabkan kepada masyarakat.

3. Dengan adanya program smart card diharapkan dapat meminimalisir patologi birokrasi terutama dalam hal pelayanan publik.

\section{DAFTAR RUJUKAN}

Ahmad, Irfan \& Marini Wulandari. 2015. Kelembagaan e-Government sebagai Pendukung Smart Governance. Jakarta : Balai IPTEKnet.

Ardilla, Dini. 2015.Kota Bandung Masih Jauh Bila Ingin Disebut 'Smart City'. Bandung: Galamedia News.

Arenawati. 2011.Complain Management Sebagai Wujud Akuntabilitas dalam Pelayanan Publik di Era Otonomi Daerah. Proceeding Simposium Nasional Otonomi Daerah 2011. 
Apriyani, Dwi. 2008. Digital Signature Menggunakan Sim Card. Malang: Karya Ilmiah Universitas Brawijaya.

Everett M, Rogers. 2003. Diffusion of Innovation.

Moleong, Lexy J. 2007. Metodologi Penelitian Kualitatif. Bandung: PT Remaja Rosdakarya.

Nurmandi, Ahmad. 2015. Manajemen Perkotaan : Teori Organisasi, Perencanaan, Perumahan, Pelayanan dan Transportasi Mewujudkan Kota Cerdas. Yogyakarta : JKSG UMY.

Hamburg, Christian and Andreas Furst. 2005. How Organizational Complaint Handling Drive Customer Loyalty An Analysis of The Mechanistic and The Organics Approach, Journal Of Marketing, July 2005.

Hendro, Muliarto. 2015. Konsep Smart City; Smart Mobility. Bandung : SAFFK-MPWK ITB.

Kompasiana. 2014. Prime Access Card, Smart Card for Smart City. (http://www.kompasiana.com/widyatharjono/prime-access-cardsmart-card-for-smart-city 54f35f457455137c2b6c738f)

Lovelock, C, 1994, Product Plus, New York : McGraw-Hill, Inc.

Sangkala.2013. Innovative Government, Yogyakarta: Capiya Publishing.

Sudaryono.2014. Konsep Smart City untuk Kota-Kota di Indonesia .Magister Parencanaan Kota dan Daerah UGM.

Suwarno, Yogi. 2008. Inovasi di Sektor Publik. Jakarta : STIA-LAN Press.

Zuhriyati, Erni dkk. 2012. Kepemimpinan Transformatif Dalam Inovasi Pemerintah di Pemerintahan Kota Yogyakarta di Era Herry Zudianto. Yogyakarta: JKSG.

Undang-Undang No.23 Tahun 2014 Tentang Pemerintahan Daerah. 